Retruque

\title{
UNHA REFLEXIÓN SOBRE O PORTO
}

Julia Fernández de Caleya Blankemeyer Universidade da Coruña 

A observación do Porto desde o aire, despois da lectura do relatorio de Álvaro Domingues, deume, así e todo, unha idea bastante clara da evolución desta cidade ao longo de varios séculos.

Explícasenos a importancia de todos os centros históricos, fortalezas, edificios relixiosos e administrativos que deixaron a súa pegada como elementos que constitúen a historia da cidade e, asemade, dos espazos verdes que, ás veces, os acompañan, dando unha esponxosidade, creando un protagonismo urbano importante do «verde de detalle».

Fálasenos da importancia do viñedo e os seus viños, que na súa orixe se vincularon fortemente ás ribeiras do río polo que foron transportados, onde se concentraron os grandes almacéns e adegas que condicionaron notablemente a vida da cidade, pero tamén do comercio crecente con Inglaterra, que fixo que estes viños fosen uns dos preferidos neste país, mesmo superando os franceses, italianos e españois, o que tivo unha importancia fundamental para o Porto e o seu desenvolvemento.

A cidade do Porto, que conta con elementos paisaxísticos destacados como o río, o mar, a súa agricultura vinícola, desenvolveu as infraestruturas de apoio necesarias para comercializar por barco -portos- e posteriormente por terra -pontes- os seus produtos e aumentou así o seu crecemento económico en ambas as dúas ribeiras do Douro.

Contemplando esta cidade e o seu crecemento, vemos como aproveitou os elementos paisaxísticos dominantes, o río, o mar, a marcada topografía, e conseguiu así medrar sen que por iso perdera a conexión co verde da súa paisaxe urbana, tanto no tocante aos seus edificios emblemáticos, como ás súas viñas ou aos montes circundantes.

As prazas, os parques, os lugares emblemáticos á beira do río e a costa, pero tamén a súa distribución territorial equilibrada, reúnen todos os ingredientes para poder tecer unha trama verde vinculante entre eles. Estes eran os obxecti- 
vos do planeamento moderno iniciado por Olmstead, o primeiro arquitecto paisaxista así denominado.

A conexión da cidade e os seus distintos barrios por medio de fermosos paseos, zonas peonís e prazas fai que o Porto teña unhas posibilidades das que outras cidades carecen. Vendo as imaxes que presento, pode apreciarse unha «distribución do verde organizada» e planificada de forma equilibrada, o que lle dá ao Porto unha vantaxe que non pode desaproveitar para gañar o futuro.

A súa propia topografía xerou unha forma de utilizar eses accidentes e deulles un carácter único á unión das súas dúas ribeiras e ás súas pontes.

Nesta exposición pretendo destacar algúns exemplos comparativos de como o seguimento de determinados modelos en Europa e nos Estados Unidos teñen creado unhas cidades máis acolledoras para os seus habitantes pola proximidade que se lles brinda para ter un acceso fácil ás zonas verdes, aos seus espazos públicos e aos seus diversos parques históricos.

O Porto, que se desenvolveu cunha distribución moi ben equilibrada dos espazos verdes, brinda as posibilidades de vincular estes lugares entre si, favorecendo o crecemento futuro e a súa paisaxe urbana. Un bo expoñente sería París e o modo en que logrou unir os parques e as zonas históricas emblemáticas, como o Bois de Bologne a través dos Campos Elíseos coas Tullerías, por medio do bulevar.

Os exemplos traídos están baseados en modelos como o dos Greenbelts de Howard nos seus New Towns, que poden verse na imaxe do gran Londres transversal, onde o cidadán pode camiñar seguindo pautas non afastadas dos espazos verdes. Outro exemplo sería Viena co Ring.

O Porto, a través das imaxes aéreas, transmite a mesma sensación de que se poden realizar percorridos peonís, como no caso de Essen, que lle permitan completar o abano de posibilidades para crear vínculos entre as súas partes cunha boa trama plantada.

Outro exemplo pode ser a cidade de Oslo, onde vemos a importancia da xeografía, o río, as pendentes, como a causa orixinaria da súa trama verde.

O Porto débelle á accidentada topografía a súa forma e o seu carácter persoal, coas espectaculares pontes. As marxes verdes do río confirman a adecuación da súa presenza ao lugar, como acontece no parque fluvial de Iugoslavia.

Con estes argumentos pode apreciarse no Porto un desenvolvemento harmónico, que lle permitiu resolver os problemas, quizais de forma intuitiva pero 
sen dúbida intelixente, sen hipotecar o seu futuro e sen destruír a cidade e conservando as posibilidades de combinar o seu deseño coa modernidade que lle traen outras industrias necesarias como son as novas tecnoloxías, o turismo, etc., ás que non pode nin debe renunciar.

Seguindo os mesmos modelos que observamos no Ruhr, vemos como as industrias, a vivenda, a historia ou a cultura poden apoiarse nas súas formas territoriais para salvagardar a natureza nos puntos máis sensibles, entrelazándose unhas coas outras; é a zona de maior poboación de Alemaña e así e todo non se nota. Nas súas valgadas ou lugares de cultivo, sitúan os bosques e crean os espazos verdes demandados pola poboación circundante.

Penso que é importante aprender destes bos exemplos da nosa cultura europea, na que moitos medramos e onde uns influímos nos outros, para que, sen perder a identidade, poidamos mellorar o que temos sen arruinalo, vendo como resolveron os problemas da industrialización cando alí se lles presentaron. O obxectivo é lograr que o benestar e o progreso continúen, pero sen arruinar o noso medio natural, tan vulnerable, porque del vivimos e nos alimentamos a maioría de nós. 